\title{
Reaction to Escherichia Coli Endotoxin in Adult Rats Neonatally Exposed to Different Endotoxins: Timing of Puberty and Levels of Gonadotropins
}

\author{
Neonatal Dönemde Farklı Endotoksinlere Maruz Kalan Sıçanların \\ Erişkinlik Döneminde Escherichia Coli Endotoksinine Yanıtları: Pubertaya \\ Erişim Ve Plazma Gonadotropin Düzeyleri
}

\author{
(D)Cihat Ucar ${ }^{1}$, DTuba Ozgocer², $\mathbb{D}$ Sedat Yildiz ${ }^{3}$ \\ 'Adıyaman University, Faculty of Medicine, Department of Physiology, Adıyaman, Turkey \\ ${ }^{2}$ Harran University, Faculty of Medicine, Department of Physiology, Şanliurfa, Turkey \\ 3ंnönü University, Faculty of Medicine, Department of Physiology, Malatya, Turkey \\ Copyright@Author(s) - Available online at www.dergipark.org.tr/tr/pub/medr \\ Content of this journal is licensed under a Creative Commons Attribution-NonCommercial 4.0 International License.
}

\begin{abstract}
Aim: Neonatal bacterial infections appear to program immune system in a sexually dimorphic way and are associated with perturbed neuronal development. Bacterial cell wall components or endotoxins cause similar effects, and therefore, are used as experimental models. Aim of the current study was to assess the effects of neonatal exposure to different bacterial endotoxins on timing of puberty and to investigate the reaction to Echerichia (E.) coli endotoxin on plasma gonadotropin levels during adulthood.

Material and Method: Female $(n=28)$ and male $(n=28)$ rat pups were injected intraperitoneally with sterile saline solution $(n=7), 100 \mathrm{ug} / \mathrm{kg}$ Escherichia coli (0111:B4) endotoxin $(n=7)$, Salmonella enterica typhimurium endotoxin $(n=7)$ or Klebsiella pneumoniae endotoxin ( $n=7)$ on neonatal day 7 . Timing of puberty was assessed daily by observing vaginal opening. All animals were injected intraperitoneally with a different E. coli serotype (026:B6) at $100 \mathrm{ug} / \mathrm{kg}$ doses on postnatal day 80 and four hours post-injection, blood samples and gonads were collected. Blood was used for gonadotropin ( $\mathrm{LH}$ and $\mathrm{FSH}$ ) analyzes. Females and males were compared by Kruskall Wallis $\mathrm{H}$ test. Multiple comparisons were made by Mann Whitney $U$ test with Bonferroni correction. An alpha level of $P<0.05$ was accepted as significant.

Results: No effects of neonatal and adulthood endotoxin exposures were observed on body weight ( $p>0.05)$ No effects of neonatal endotoxin exposures were observed on timing of puberty $(p>0.05)$. Neonatal and adulthood endotoxin exposures did not affect FSH and LH levels and gonad weights $(p>0.05)$

Conclusion: It might be concluded that effects of single neonatal exposure to different endotoxins are corrected before the commencement of the puberty, and hence, pubertal development is not affected.
\end{abstract}

Key words: Neonatal period; Different LPS; Puberty; Gonadotropins Levels

$\mathrm{Oz}$

Amaç: Neonatal bakteriyel enfeksiyonların bağışıklık sistemini cinsiyete bağımlı olarak programladığı ve bunun nöronal gelişimin bozulması ile ilişkili olduğu bildirilmiştir. Bakteri hücre duvarı unsurları ya da endotoksinler de benzer etkiler yapmakta ve bu amaçla deneysel modellerde kullanılmaktadırlar. Mevcut çalışmanın amacı, neonatal dönemde farklı bakteriyel endotoksinlerin pubertaya erişim üzerine etkilerini araştırmak ve erişkinlik döneminde yapılan Escherichia (E.) coli endotoksininin plazma gonadotropinleri üzerine etkilerini incelemekti.

Materyal ve Metot: Neonatal 7. günde dişi ve erkek sıçan yavrularına $100 \mathrm{ug} / \mathrm{kg}$ dozunda steril salin ( $\mathrm{n}=7$ ), E. coli (O111:B4) endotoksini $(n=7)$, Salmonella enterica typhimurium endotoksini $(n=7)$ veya Klebsiella pneumoniae endotoksini $(n=7)$ intraperitonel olarak enjekte edildi. Puberta zamanı, vajinal açıklığın günlük gözlemlenmesi ile tespit edildi. Postnatal 80. günde tüm gruplara farklı bir E. coli serotipi olan E. coli (026:B6) LPS enjeksiyonu (100ug/kg) yapıldı ve enjeksiyondan 4 saat sonra gonadlar ve kan örnekleri alındı. Kanda gonadotropin (FSH ve LH analizi) analizleri yapıldı. Erkek ve dişilerin gruplar arası karşılaştırılmasında Kruskal Wallis $\mathrm{H}$ testi, çoklu karşılaştırmalarda Bonferroni düzeltmeli Mann Whitney U testi kullanıldı. İstatistiksel olarak $p<0.05$ değeri anlamlı kabul edildi.

Bulgular. Vücut ağırlığı üzerine neonatal ve erişkin dönem endotoksin maruziyetin etkisinin olmadığı gözlendi ( $p>0.05)$. Pubertaya erişim üzerine neonatal dönemde farklı endotoksin maruziyetinin etkisinin olmadığı gözlendi ( $p>0.05)$. Neonatal dönemde ve erişkinlik dönemindeki endotoksin maruziyetleri FSH ve LH seviyelerini ve gonad ağırlıklarını etkilemedi $(p>0.05)$.

Sonuç: Elde edilen bulgulara göre, neonatal dönemde tek doz endotoksin maruziyetinin pubertaya erişimi etkilemediği ve incelenen tüm endotoksinlere karşı verilen yanıtın benzer olduğu sonuçlarına varıımıştır. Dolayısıyla, tek doz endotoksin üreme sistemini etkilemediği veya neonatal dönemde yapılan endotoksin enjeksiyonlarının oluşturduğu etkilerin pubertal döneme kadar giderildiği düşünülebilir.

Anahtar Kelimeler. Neonatal dönem; Farklı LPS; Puberta; Gonadotropin düzeyleri

Geliş Tarihi / Received: 20.01.2021 Kabul Tarihi / Accepted: 05.02.2021

Sorumlu Yazar /Corresponding Author. Sedat Yildiz,Inönü University, Faculty of Medicine, Department of

Physiology, Malatya, Turkey, E-mail: sedat.yildiz@inonu.edu.tr 


\section{INTRODUCTION}

People are constantly exposed to toxins caused by the molecules related to microorganisms (1). Bacteriainduced endotoxins are present everywhere around us $(2,3)$. It can be found in the houses, healthcare organizations, agricultural lands, and wastes in different rates from nanograms to micrograms (3). Actually, there are microorganisms producing endotoxin within the microbiota that forms our digestive system (4). We are exposed to such endotoxins depending on change in the intestinal permeability (5). As a result, the number of endotoxins in the bloodstream increases and they can cause low-grade chronic inflammation, and may play a role in the development of many serious chronic diseases (obesity, atherosclerosis, neurological diseases) $(5,6)$.

Bacterial infections cause a strong response in the immune system of the organism and thus, create inflammatory stress. The effect mode of the immune stress on reproductive functions is exactly understood and it is thought that it may occur via the endocrine, paracrine, and neuronal systems (7). Especially the infections exposed in the neonatal period affect the reproductive system (8). It is reported that exposure to lipopolysaccharide (LPS), which is a bacterial endotoxin obtained from the gramnegative bacterial cell wall, in the neonatal period affects the Hypothalamic- Pituitary Adrenal axis and causes the disruption of the ovarian cycle $(9,10)$. On the other hand, exposure to endotoxin in adulthood also affects the reproductive system (8).

The aim of the present study was to investigate the effects of different bacterial endotoxins on access to puberty in the neonatal period and to examine the effects of a different Escherichia (E.) coli endotoxin on plasma gonadotropins in adulthood.

\section{MATERIAL AND METHODS}

\section{Animals and Experiment Protocols}

Pregnant Sprague-Dawley rats (INU-DEHUM, Turkey) were housed under controlled conditions (12L:12D; 22 $\left.\pm 2{ }^{\circ} \mathrm{C}\right)$ and supplied with ad libitum food and water. Female $(n=28)$ and male $(n=28)$ rat pups were injected intraperitoneally with sterile saline solution $(n=7), 100 \mathrm{ug} / \mathrm{kg}$ Escherichia coli (0111:B4) endotoxin $(n=7)$, Salmonella enterica typhimurium endotoxin $(n=7)$ or Klebsiella pneumoniae endotoxin $(n=7)$ on neonatal day 7 . Timing of puberty was assessed daily by observing vaginal opening (11). All animals were injected intraperitoneally with a different $E$. coli serotype $(026: \mathrm{B} 6)$ at $100 \mathrm{ug} / \mathrm{kg}$ doses on postnatal day 80 and four hours' post-injection, blood samples and gonads were collected. Blood was used for gonadotropin ( $\mathrm{LH}$ and FSH) analyzes. This study was approved Animal Research Ethics Committee of Inonu University Medical Faculty (Protocol \# 2010/54) (Figure 1).

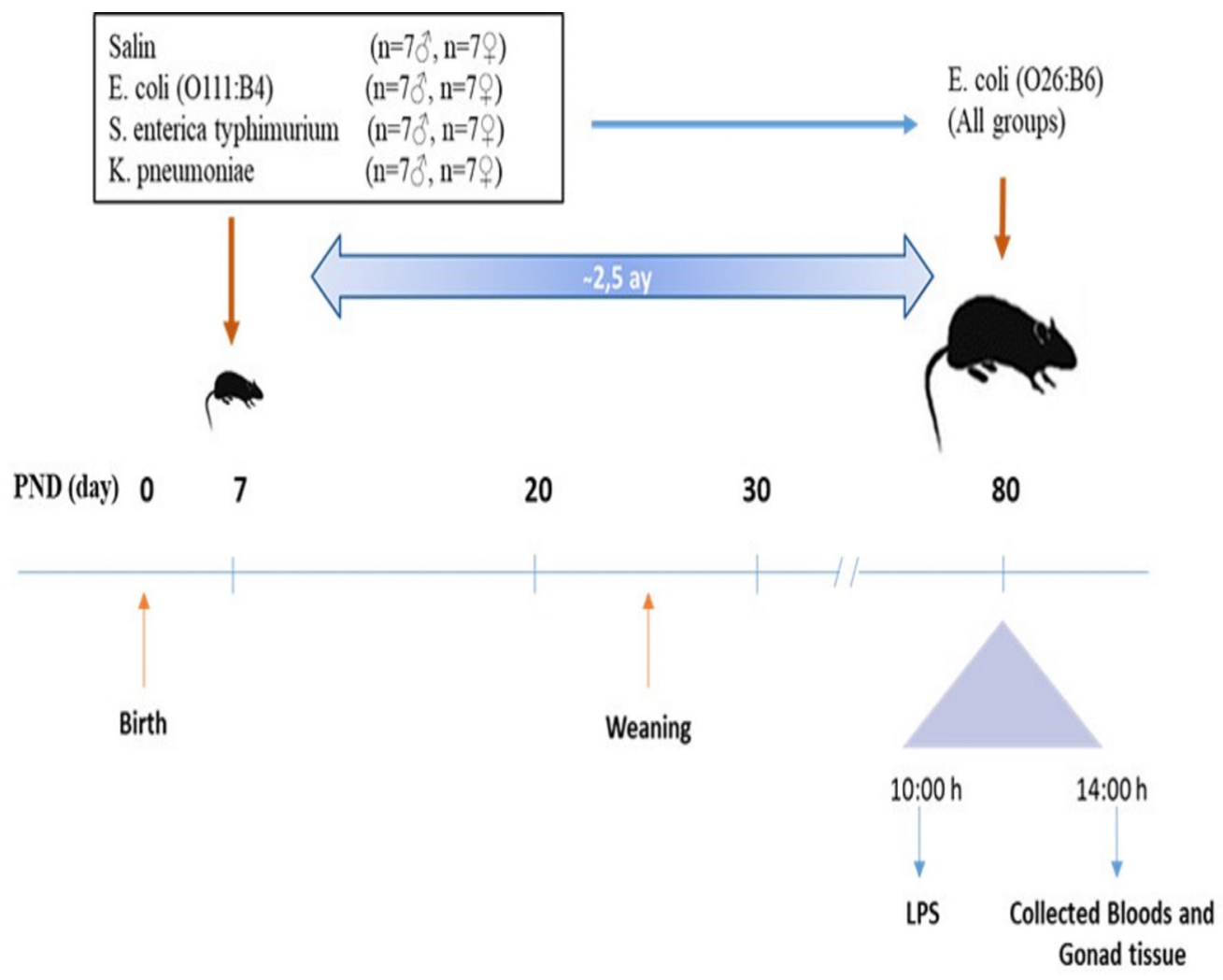

Figure 1. Experimental Protocol 


\section{LH and FSH enzymeimmunoassays}

LH and FSH were analyzed according to Pappa et al. (12) with some modifications. Briefly, 96-well immunoplates (Nunc, Roskilde, Denmark) were coated with rat LH or rat FSH. Serum samples or standards were preincubated with primary antibodies and were then transferred into coated plates for competition with antigens on the solid phase. Plates were washed and the secondary antibody conjugated to streptavidin peroxidase was added into each well and color was developed by using tetramethylbenzidine as the substrate. Plates were read at $450 \mathrm{~nm}$ using a plate reader (Biotek, Synergy HT, USA). Rat $\mathrm{LH}$, rat FSH and primary antibodies (rabbit anti-rat $\mathrm{LH}$ and rabbit anti-rat FSH) were obtained from Dr. A.F. Parlow (NIDDK, NIH, USA) and secondary antibodies (goat anti-rabbit $\operatorname{lgG}$ ) conjugated to streptavidin peroxidase was purchased from Sigma (Sigma-Aldrich, Taufkirchen, Germany). Sensitivity of the assays was $1 \mathrm{ng} / \mathrm{ml}$ for $\mathrm{LH}$ and $2 \mathrm{ng} / \mathrm{ml}$ for FSH. Inter- and intra-assay coefficients of variations were below $8 \%$ for both LH and FSH.

\section{Statistical analysis}

SPSS 26.0 program was used for statistical analysis.

Females and males were compared by Kruskall Wallis $\mathrm{H}$ test. Multiple comparisons were made by Mann Whitney $\mathrm{U}$ test with Bonferroni correction. Values of $\mathrm{p}<0.05$ were considered significant. All results were expressed as means \pm standart error (SE).

\section{RESULTS}

Different LPS injection in the neonatal period did not affect timing of puberty $(p>0.05)$ Subsequent to the different LPS injection in the neonatal period, a different LPS injection on the postnatal 80th day did not affect gonadotropin (FSH and LH) levels, gonad weights, and body weights ( $p>0.05)$. Findings for male and female rats are summarized in table 1 and figure 2.

Table 1. Body and gonad weight, puberty, serum LH and FSH concentrations of the groups

\begin{tabular}{|c|c|c|c|c|c|c|}
\hline & & Salin $(n=7)$ & E.coli $(n=7)$ & Salmonella $(n=7)$ & Klebsiella $(n=7)$ & $P$ value \\
\hline & Body Weight (g) & $253 \pm 64$ & $314 \pm 39$ & $300 \pm 41$ & $282 \pm 69$ & $>0.05$ \\
\hline & Puberty (day) & $41 \pm 4$ & $41 \pm 4$ & $41 \pm 3$ & $41 \pm 4$ & $>0.05$ \\
\hline \multirow[t]{6}{*}{ Men } & FSH (ng/ml) & $24.1 \pm 5.33$ & $16.5 \pm 1.56$ & $19.3 \pm 3.27$ & $15.72 \pm 3.23$ & $>0.05$ \\
\hline & LH (ng/ml) & $1.75 \pm 0.60$ & $1.67 \pm 0.50$ & $2.65 \pm 1.93$ & $3.02 \pm 2.17$ & $>0.05$ \\
\hline & Gonad Weight (g) & $0.93 \pm 0.45$ & $1.33 \pm 0.30$ & $1.25 \pm 0.47$ & $1.49 \pm 0.35$ & $>0.05$ \\
\hline & & Salin $(n=7)$ & E.coli $(n=7)$ & Salmonella $(n=7)$ & Klebsiella $(n=7)$ & $P$ value \\
\hline & Body Weight (g) & $221 \pm 10$ & $219 \pm 20$ & $216 \pm 22$ & $205 \pm 24$ & $>0.05$ \\
\hline & Puberty (day) & $40 \pm 4$ & $43 \pm 4$ & $43 \pm 4$ & $43 \pm 3$ & $>0.05$ \\
\hline \multirow[t]{3}{*}{ Women } & FSH (ng/ml) & $15.27 \pm 10.37$ & $11.31 \pm 1.32$ & $12.16 \pm 5.06$ & $11.96 \pm 1.73$ & $>0.05$ \\
\hline & LH (ng/ml) & $3.86 \pm 2.55$ & $3.14 \pm 1.62$ & $3.11 \pm 1.17$ & $2.33 \pm 0.9$ & $>0.05$ \\
\hline & Gonad Weight (g) & $0.17 \pm 0.03$ & $0.27 \pm 0.13$ & $0.15 \pm 0.02$ & $0.13 \pm 0.02$ & $>0.05$ \\
\hline
\end{tabular}



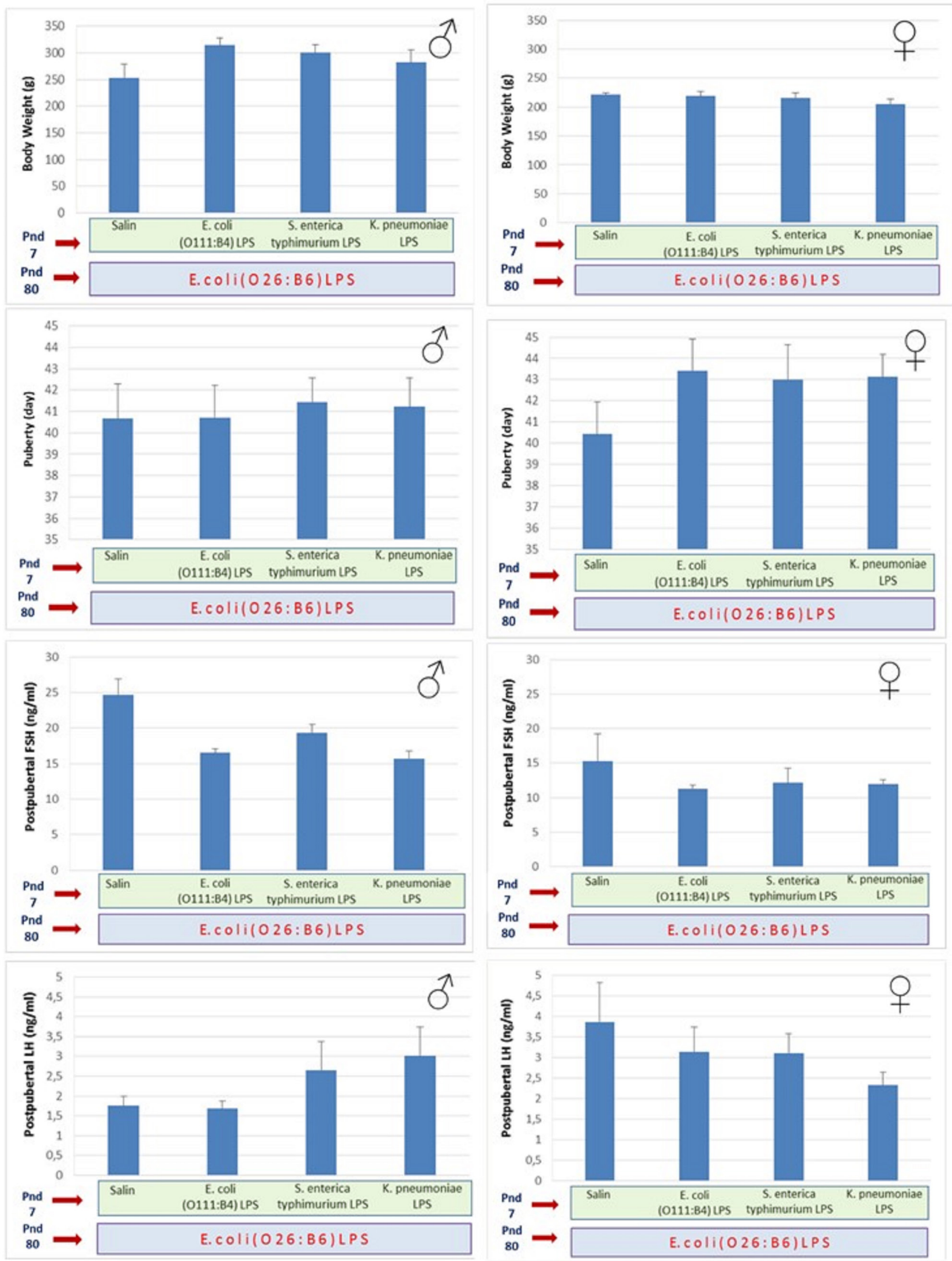

Figure 2. Body and gonad weight, puberty, serum LH and FSH concentrations of the groups 


\section{DISCUSSION}

Endotoxins are found in the digestive system of humans and animals as endogenous also they are present everywhere in our surrounding. When the findings obtained from the study were examined, different bacterial endotoxin LPS injections had no effect on puberty and the live weight. On the other hand, the administration of an endotoxin LPS that is different from LPS injected in the neonatal period had no effect on gonadotropin (FSH and $\mathrm{LH}$ ) in the short term. Two LPS injections performed at different times throughout the lifetime did not affect the gonad and the ovarian weight.

Different effects of LPS administration on reproductive system are determined in the neonatal period (8). It is reported that single dose of LPS injection to rat offsprings has accelerated puberty $(11,13)$. On the other hand, other authors have observed a delayed access to puberty in the rats that received a single LPS injection $(10,14)$. When the methods of the studies are examined carefully, the reasons for the different effects of LPS administration on puberty in the neonatal period can be as follows; 1. LPS source obtained from different bacteria, 2. LPS obtained from different serotypes of bacteria, 3. The day, dose, and number of the LPS injection. One of the essential purposes of the current study was different endotoxin administration. However, puberty was not affected from different LPS administration in the present study. LPS injection of the rat offsprings could be balanced by increasing their weight gain. In a study, it was reported that a single dose LPS administration caused rapid weight gain in prepubertal period (11). In the present study, in response to the LPS administration, weight gain could be increased and the effect on puberty could be compensated. On the other hand, it is reported that LPS administration in the neonatal period delays puberty (14). However, the day of injection is the postnatal 3rd5th days. In the present study, the injection was done on the postnatal 7th day and as a single injection. When the studies were examined, it was decided to administer different endotoxins on the postnatal 7th day and as a single dose $(100 \mu \mathrm{g} / \mathrm{kg})$ in the present study by considering different LPS sources and serotypes used. Thus, it can be thought that single dose of endotoxin did not affect the reproductive system or the effects of endotoxin injections in the neonatal period were eliminated until the pubertal period.

In the present study, a single dose of LPS administration in the neonatal period and a different endotoxin administration on the postnatal 80th day had no effect on FSH and LH. It had similar findings with a previous study (11). However, in a study, LPS injection administrated in neonatal period and in adulthood decreased the $\mathrm{LH}$ level $(15,16)$. When the differences between the studies were examined, it may be caused by the bloodletting hours. In the present study, blood was taken following decapitation4 hours after the LPS injection. In future studies, it will be appropriate to attach a catheter, take blood at certain intervals and examine it by considering the circadian rhythm of gonadotropins.

Financial disclosures: All authors report no financial interests or potential conflicts of interest.

Conflict of Interest: The authors declare that they have no competing interest.

Ethical approval: Prior to the study, written permission was obtained from the institutions in which the study was conducted, and ethical approval was obtained from the Scientific Research and Publication Ethics Committee of the Malatya Inonu University of Health Sciences in Turkey on Number 2010/54.

\section{REFERENCES}

1. Heederik D, von Mutius E. Does diversity of environmental microbial exposure matter for the occurrence of allergy and asthma? J Allergy Clin Immunol 2012;130:44-50.

2. Rylander R. Endotoxin in the environment--exposure and effects. J Endotoxin Res 2002;8:241-52.

3. Duquenne P, Ambroise D, Görner P, et al. Exposure to airborne endotoxins among sewer workers: an exploratory study. Ann Occup Hyg 2014;58:283-93.

4. Glaros TG, Chang S, Gilliam EA, et al. Causes and consequences of low grade endotoxemia and inflammatory diseases. Front Biosci (Schol Ed) 2013 1;5:754-65.

5. Moreira AP, Texeira TF, Ferreira AB, et al. Influence of a high-fat diet on gut microbiota, intestinal permeability and metabolic endotoxaemia. Br J Nutr 2012;108:801-9.

6. Hawkesworth S, Moore SE, Fulford AJ, et al. Evidence for metabolic endotoxemia in obese and diabetic Gambian women. Nutr Diabetes 2013;3:e83.

7. Melmed S. Series introduction. The immuno-neuroendocrine interface. J Clin Invest 2001;108:1563-6.

8. Kane L, Ismail N. Puberty as a vulnerable period to the effects of immune challenges: Focus on sex differences. Behav Brain Res 2017;320:374-82.

9. Battaglia DF, Krasa HB, Padmanabhan V, et al. Endocrine alterations that underlie endotoxin-induced disruption of the follicular phase in ewes. Biol Reprod 2000;62:45-53.

10. Wu XQ, Li XF, Ye $B$, et al. Neonatal programming by immunological challenge: effects on ovarian function in the adult rat. Reproduction 2011;141:241-8.

11. Ozgocer T, Yildiz S, Elbe H, Vardi N. Endotoxin exposure and puberty in female rats: the role of nitric oxide and caspase- 1 inhibition in neonates. Can J Physiol Pharmacol 2015;93:603-14.

12. Pappa A, Seferiadis K, Marselos M, et al. Development and application of competitive ELISA assays for rat $\mathrm{LH}$ and FSH. Theriogenology 1999;51:911-26.

13. Sominsky L, Meehan CL, Walker AK, et al. Neonatal immune challenge alters reproductive development in the female rat. Horm Behav 2012;62:345-55.

14. Walker AK, Hiles SA, Sominsky $L$, et al. Neonatal lipopolysaccharide exposure impairs sexual development 
and reproductive success in the Wistar rat. Brain Behav Immun 2011;25:674-84.

15. Iwasa T, Matsuzaki T, Murakami M, et al. Neonatal immune challenge affects the regulation of estrus cyclicity and feeding behavior in female rats. Int $J$ Dev Neurosci 2009;27:111-4.
16. Li XF, Kinsey-Jones JS, Knox AM, et al. Neonatal lipopolysaccharide exposure exacerbates stress-induced suppression of luteinizing hormone pulse frequency in adulthood. Endocrinology 2007;148:5984-90. 